\title{
Front Matter: Volume 11008
}

, "Front Matter: Volume 11008," Proc. SPIE 11008, Autonomous Air and Ground Sensing Systems for Agricultural Optimization and Phenotyping IV, 1100801 (30 July 2019); doi: 10.1117/12.2537997

SPIE Event: SPIE Defense + Commercial Sensing, 2019, Baltimore, MD, United SPIE. States 


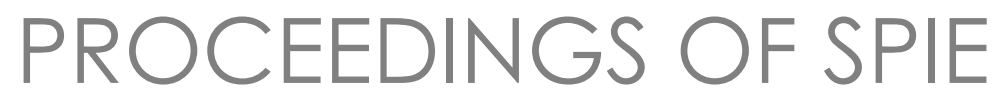

\title{
Autonomous Air and Ground Sensing Systems for Agricultural Optimization and Phenotyping IV
}

\author{
J. Alex Thomasson \\ Mac McKee \\ Robert J. Moorhead \\ Editors
}

15-16 April 2019

Baltimore, Maryland, United States

Sponsored and Published by

SPIE 
The papers in this volume were part of the technical conference cited on the cover and title page. Papers were selected and subject to review by the editors and conference program committee. Some conference presentations may not be available for publication. Additional papers and presentation recordings may be available online in the SPIE Digital Library at SPIEDigitalLibrary.org.

The papers reflect the work and thoughts of the authors and are published herein as submitted. The publisher is not responsible for the validity of the information or for any outcomes resulting from reliance thereon.

Please use the following format to cite material from these proceedings:

Author(s), "Title of Paper," in Autonomous Air and Ground Sensing Systems for Agricultural Optimization and Phenotyping IV, edited by J. Alex Thomasson, Mac McKee, Robert J. Moorhead, Proceedings of SPIE Vol. 11008 (SPIE, Bellingham, WA, 2019) Seven-digit Article CID Number.

ISSN: 0277-786X

ISSN: 1996-756X (electronic)

ISBN: 9781510626812

ISBN: 9781510626829 (electronic)

Published by

SPIE

P.O. Box 10, Bellingham, Washington 98227-0010 USA

Telephone +1 3606763290 (Pacific Time) · Fax +1 3606471445

SPIE.org

Copyright (C) 2019, Society of Photo-Optical Instrumentation Engineers.

Copying of material in this book for internal or personal use, or for the internal or personal use of specific clients, beyond the fair use provisions granted by the U.S. Copyright Law is authorized by SPIE subject to payment of copying fees. The Transactional Reporting Service base fee for this volume is $\$ 18.00$ per article (or portion thereof), which should be paid directly to the Copyright Clearance Center (CCC), 222 Rosewood Drive, Danvers, MA 01923. Payment may also be made electronically through CCC Online at copyright.com. Other copying for republication, resale, advertising or promotion, or any form of systematic or multiple reproduction of any material in this book is prohibited except with permission in writing from the publisher. The CCC fee code is 0277$786 \mathrm{X} / 19 / \$ 18.00$.

Printed in the United States of America by Curran Associates, Inc., under license from SPIE.

Publication of record for individual papers is online in the SPIE Digital Library.

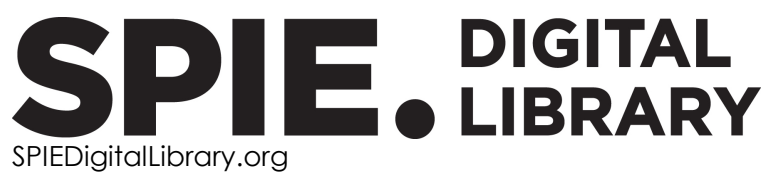

Paper Numbering: Proceedings of SPIE follow an e-First publication model. A unique citation identifier (CID) number is assigned to each article at the time of publication. Utilization of CIDs allows articles to be fully citable as soon as they are published online, and connects the same identifier to all online and print versions of the publication. SPIE uses a seven-digit CID article numbering system structured as follows:

- The first five digits correspond to the SPIE volume number.

- The last two digits indicate publication order within the volume using a Base 36 numbering system employing both numerals and letters. These two-number sets start with $00,01,02,03,04$, 05, 06, 07, 08, 09, 0A, OB ... 0Z, followed by 10-1Z, 20-2Z, etc. The CID Number appears on each page of the manuscript. 


\title{
Contents
}

\author{
$\checkmark \quad$ Authors \\ vii Conference Committee
}

\section{ADVANCED SENSORS FOR AGRICULTURE OPTIMIZATION AND PHENOTYPING}

1100802 Estimation of surface thermal emissivity in a vineyard for UAV microbolometer thermal cameras using NASA HyTES hyperspectral thermal, and Landsat and AggieAir optical data [1 1008-1]

$1100803 \quad$ Estimation of crop latent heat flux from high resolution thermal imagery [1 1008-2]

1100804 The impact of shadows on partitioning of radiometric temperature to canopy and soil temperature based on the contextual two-source energy balance model (TSEB-2T) (Best Paper Award) [1 1008-3]

1100805 Impact of camera lens angle and sUAS flying altitude on spatial crop canopy temperature evaluation [1 1008-4]

1100806 Comparing the effectiveness of hyperspectral and multispectral data in detecting citrus nitrogen and water stresses [1 1008-5]

1100807 Using hyperspectral imagery to detect water stress in a vineyard [1 1008-6]

1100808 Detection of diseases and pests on images captured in uncontrolled conditions from tea plantations [1 1008-33]

\section{SYSTEMS FOR PRODUCING HIGH-QUALITY AGRICULTURAL REMOTE-SENSING DATA WITH SUAS}

1100809 Software requirements, architecture, design, and results of a modular, multispectral, scientific quality unmanned aerial system payload for civilian remote sensing [1 1008-8]

$11008 \mathrm{OB} \quad$ Coordination and control for automatic mobile ground control points in agricultural remote sensing [11008-10]

11008 OD Small plot identification from video streams for high-throughput phenotyping of large breeding populations with unmanned aerial systems [1 1008-12]

CONTROL AND INTEGRATION OF UAS SENSING SYSTEMS FOR AGRICULTURAL OPTIMIZATION AND PHENOTYPING

11008 OE UAV-based multi-sensor multi-platform integration for high throughput phenotyping [1 1008-13] 
11008 OG Drones coordination protocols in the precision agriculture context [1 1008-15]

$11008 \mathrm{OH} \quad$ An energy aware smart station for an UAV fleet in the smart farming application [11008-16]

\section{ANALYTICS FOR UAV REMOTE SENSING IN AGRICULTURE}

$11008 \mathrm{OL} \quad$ Validation of digital surface models (DSMs) retrieved from unmanned aerial vehicle (UAV) point clouds using geometrical information from shadows [11008-19]

11008 OM Assessment of different image enhancement and classification techniques in detection of volunteer cotton using UAV remote sensing [11008-20]

11008 ON Plant-by-plant level classifications of cotton root rot by UAV remote sensing [1 1008-21]

$1100800 \quad$ Unmanned aerial system based tomato yield estimation using machine learning [1 1008-22]

11008 OP $\quad$ UAS based Tomato Yellow Leaf Curl Virus (TYLCV) disease detection system [1 1008-23]

$110080 Q \quad$ Machine learning models for predicting lettuce health using UAV imageries [1 1008-24]

11008 OR Machine learning approaches to automate weed detection by UAV based sensors [1 1008-25]

11008 OS Estimation of soil moisture at different soil levels using machine learning techniques and unmanned aerial vehicle (UAV) multispectral imagery [1 1008-26]

\section{UAV AND GROUND-BASED SENSING APPLICATIONS FOR AGRICULTURAL OPTIMIZATION AND} PHENOTYPING

11008 OU Improving soybean breeding using UAS measurements of physiological maturity [1 1008-27]

$110080 \mathrm{X} \quad$ Use of unmanned aerial vehicle extracted data to predict health and tiller count in wheat [1 1008-30]

11008 OY Plant density estimation and weeds mapping on row crops at emergence using low altitude UAS imagery [1 1008-31]

$110080 Z$ Estimating standing biomass of exotic macrophytes using sUAS [1 1008-32]

1100811 An initial analysis of real-time sUAS-based detection of grapevine water status in the Finger Lakes wine country of upstate New York (Best Paper Award) [1 1008-35]

1100812 Application of unmanned aerial system for management of tomato cropping system [1 1008-36] 


\section{Authors}

Numbers in the index correspond to the last two digits of the seven-digit citation identifier (CID) article numbering system used in Proceedings of SPIE. The first five digits reflect the volume number. Base 36 numbering is employed for the last two digits and indicates the order of articles within the volume. Numbers start with 00, 01, 02, 03, 04, 05, 06, 07, 08, 09, OA, OB...0Z, followed by 10-1Z, 20-2Z, etc.

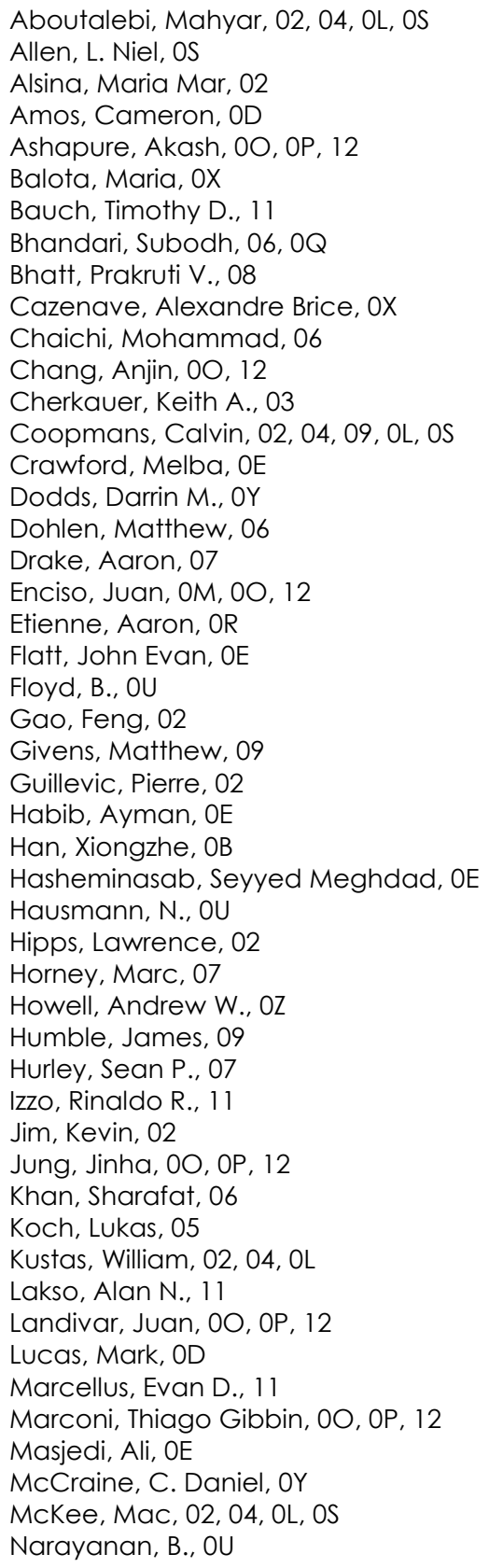

Nassar, Ayman, 02

Nieto, Héctor, 04, OL

Oakes, Joseph, OX

Oh, Sungchan, $00,0 P, 12$

Palmieri, Nunzia, $0 \mathrm{G}, \mathrm{OH}$

Pappula, Srinivasu, 08

Pham, Frank, 06, 0Q

Poland, Jesse, OD

Potrino, Giuseppe, 0G

Prabhakar, Pavithra, 05

Prince Czarnecki, Joby M., OY

Quijano, Karoll, OE

Raheja, Amar, 06, 0Q

Raimondo, Pierfrancesco, $\mathrm{OH}$

Raqueño, Nina G., 11

Ravi, Radhika, OE

Richardson, Robert J., $\mathrm{OZ}$

Ries, L., OU

Samanta, Sayantan, OM

Samiappan, Sathishkumar, OY

Sangha, Harman S., 05

Sarangi, Sanat, 08

Saraswat, Dharmendra, OR

Serianni, Abdon, $0 \mathrm{G}, \mathrm{OH}$

Sharda, Ajay, 05

Sherman, Tristan, 06

Shrestha, Amrit, OM

Thomason, Wade, OX

Thomasson, J. Alex, OB, OM, ON

Torres-Rua, Alfonso F., 02, 04, OL, OS

Tu, K., OU

van Aardt, Jan, 11

Wang, Guanghui, 05

Wang, T., ON

Wang, $\mathrm{XU}, \mathrm{OD}$

Williams, Grant, OD

Wright, Timothy, 02

Yadav, Pappu Kumar, OM

Zhou, Tian, OE

Zhu, Yan, 03 
Proc. of SPIE Vol. 11008 1100801-6 Downloaded From: https://www.spiedigitallibrary.org/conference-proceedings-of-spie on 26 Apr 2023
Terms of Use: https://www.spiedigitallibrary.org/terms-of-use 


\title{
Conference Committee
}

\author{
Symposium Chairs
}

Jay Kumler, JENOPTIK Optical Systems, LLC (United States)

Ruth L. Moser, Air Force Research Laboratory (United States)

Symposium Co-chair

John Pellegrino, Electro-Optical Systems Laboratory, Georgia Institute of Technology (United States)

Conference Chairs

J. Alex Thomasson, Texas A\&M University (United States)

Mac McKee, Utah State University (United States)

Robert J. Moorhead, Mississippi State University (United States)

Conference Program Committee

Atanu Basu, Ayata (United States)

Christoph Baver, KWS SAAT AG (Germany)

Subodh Bhandari, California State Polytechnic University, Pomona (United States)

Andrew N. French, Agricultural Research Service (United States)

Yufeng Ge, University of Nebraska-Lincoln (United States)

Cheryl McCarthy, University of Southern Queensland (Australia)

Seth C. Murray, Texas A\&M University (United States)

Haly Neely, Texas A\&M University (United States)

Boyan Peshlov, Climate Corporation (United States)

Carl Salvaggio, Rochester Institute of Technology (United States)

Michael Sama, University of Kentucky (United States)

Sindhuja Sankaran, Washington State University (United States)

Ajay Sharda, Kansas State University (United States)

Yeyin Shi, University of Nebraska-Lincoln (United States)

Session Chairs

1 Advanced Sensors for Agriculture Optimization and Phenotyping

John Alex Thomasson, Texas A\&M University (United States)

2 Systems for Producing High-Quality Agricultural Remote-Sensing Data with sUAS

Robert J. Moorhead, Mississippi State University (United States) 
3 Control and Integration of UAS Sensing Systems for Agricultural Optimization and Phenotyping

Mac McKee, Utah State University (United States)

4 Trends in UAS for Agriculture

John Alex Thomasson, Texas A\&M University (United States)

5 Analytics for UAV Remote Sensing in Agriculture

Robert J. Moorhead, Mississippi State University (United States)

6 UAV and Ground-based Sensing Applications for Agricultural Optimization and Phenotyping

Mac McKee, Utah State University (United States) 